\title{
AFTER EARTHQUAKE IN SIGI: CAN SOCIAL SUPPORT AFFECT CAREER DECISION SELF-EFFICACY?
}

\author{
Rose Mini Agoes Salim*, Kusumasari Kartika Hima Darmayanti \\ Universitas Indonesia, Indonesia \\ *e-mail: romyap@ui.ac.id
}

\begin{abstract}
An earthquake struck Central Sulawesi Province, Indonesia in 2019, and Sigi Regency was one of the most affected areas. Based on a psychological perspective, studies were significant to understand how earthquakes impacted Post-Traumatic Stress Disorder. This study aimed to examine the effect of social support on CDSE (Career Decision Self-Efficacy). As many as 141 high school students as the earthquake victims in Sigi filled out the Career Decision-Making Self-Efficacy Scale Short-Form (CDMSES-SF) and Adolescent Social Support Scale (ASSS). The data were analyzed using the multiple regression approach in IBM SPSS Software Version 23.00. The findings showed that teachers' social support successfully enhanced CDSE. Also, CDSE was significantly affected by social support received from peers. On the other hand, this study confirmed that there was no significant effect of parents' social support on CDSE. The results contributed to the career counseling program for high school students by taking into account teachers' and peers' social support.
\end{abstract}

Keywords: earthquake in Sigi, high school students, social support, career decision self-efficacy.

\section{PASCA GEMPA BUMI DI SIGI: DAPATKAH DUKUNGAN SOSIAL MEMENGARUHI EFIKASI DIRI KEPUTUSAN KARIER?}

\begin{abstract}
Abstrak: Musibah gempa bumi terjadi di Provinsi Sulawesi Tengah, Indonesia pada 2019, dan Kabupaten Sigi adalah salah satu daerah yang paling parah. Dari perspektif psikologi, penelitian penting dilaksanakan untuk memahami bagaimana gempa bumi berdampak pada Post-Traumatic Stress Disorder. Penelitian ini bertujuan untuk menguji pengaruh dukungan sosial terhadap Career Decision Self-Efficacy (CDSE). Sebanyak 141 siswa sekolah menengah yang menjadi korban gempa bumi di Sigi mengisi Career Decision-Making Self-Efficacy Scale Short-Form (CDMSES-SF) dan Adolescent Social Support Scale (ASSS). Data dianalisis dengan menggunakan pendekatan multiple regresi yang terdapat pada software IBM SPSS versi 23.00. Temuan penelitian menunjukkan bahwa CDSE dapat ditingkatkan dengan peran dukungan sosial guru. Temuan penelitian lainnya juga menunjukkan bahwa CDSE secara signifikan dipengaruhi oleh dukungan sosial teman. Di sisi lain, penelitian ini mengonfirmasi bahwa tidak terdapat pengaruh yang signifikan dari dukungan sosial orang tua terhadap CDSE. Hasil penelitian berdampak pada program konseling karier yang diberikan pada siswa sekolah menengah dengan memperhatikan dukungan guru dan teman.
\end{abstract}

Kata Kunci: gempa bumi Sigi, siswa sekolah menengah, dukungan sosial, efikasi diri keputusan karier.

\section{INTRODUCTION}

Indonesia is vulnerable to natural disasters, one of which is earthquakes. September 2018, an earthquake struck Central Sulawesi Province on the island of Sulawesi. Referring to the data from Meteorology, Climatology, and Geophysics Agency (BMKG; 2018), an earthquake struck Central Sulawesi Province, and Sigi Regency was one of the affected areas. Furthermore, Jurnaliston (2018) stated in his article on Kompas.com titled 'An earthquake with a magnitude of 5.5 hit Sigi, Central Sulawesi, that the earthquake occurred on September 28, 2019, and September 29, 2019, with the earthquake's magnitude scale recorded at 5.5 magnitudes and 7.4 magnitudes.

Regarding earthquakes, from a psychological perspective, several studies conducted as an impact of earthquakes are related to how earthquakes impact on PostTraumatic Stress Disorder (PTSD) (Pan, Liu, Deng, Liu, Yan, Tang, ... \& Xu, 2015; Wang, 
Fu, Wu, Ma, Sun, Huang, ... \& Gao, 2012; Hou, Li, Li, Hu, Liu, \& Yuan, 2011), self-efficacy (Newnham, Balsari, Lam, Kashyap, Pham, Chan, ... \& Leaning, 2017), resilience (Cretney, 2016; Pan et al., 2015), coping strategies (Mesidor \& Sly, 2019; Mooney, Tarrant, Paton, Johal, \& Johnston, 2017), emotional trauma (Dominey-Howes, 2015), and decision-making (Béjar-Pizarro, Álvarez Gómez, Staller, Luna, Pérez-López, Monserrat, ... \& Herrera, 2018; Platt \& Drinkwater, 2016). In other side, studies relating to educational psychology are still small. Some educational psychology research related to earthquakes, among them, is as done by Ho, Fan, Lai, Lo, Potash, Kalmanowitz, Nan, ... \& Chan. (2012) and O'Toole \& Friesen (2016). In the world of education, O'Toole \& Friesen (2016) conducted a training to manage the emotions of teachers after the earthquake that occurred in Christchurch, New Zealand. Meanwhile, Ho et al. (2012) found that the training they conducted was significantly able to improve teaching selfefficacy of teachers in Sinchuan, Mainland China after the earthquake which resulted in the death of 9,000 teachers and children.

Furthermore, even in the aftermath of the earthquake with some economic, educational and other limitations, high school students should pay attention to their future, especially education and careers. For high school students, they are faced with the process of choosing a study program that suits their careers. For this reason, they are faced with situations where they make decisions about their study programs and careers for their future.

The United Nations Children's Fund (UNICEF, 2016) adds that in times of crisis (e.g. disasters and emergencies), education for students is important. In addition to food, drinks, medicines, and other necessities, education is equally important (UNICEF, 2017). With education, they are expected to be able to pay for a better future (UNICEF, 2016). Education can improve mental processes and facilitate their interests and potentials. In addition, they are future leaders, so it depends on the country depends on them. In the future, they will take an active role in the community that makes a positive contribution (UNICEF, 2017). A metaanalysis conducted by Cassarino-Perez, Crous, Goemans, Montserrat, \& Sarriera (2018) found that education related to the future of students, whichever, career was largely determined by the level of education (e.g. at the university level) (Cassarino-Perez et al., 2018).

Furthermore, in addition to education having a role in shaping their real contribution in society, what needs to be considered is how they decide the role they want to take. Determination of the role is part of deciding a career. Then, in deciding future careers, students need confidence in their abilities in deciding on careers that are of their interest and passion, called with Career Decision Self-Efficacy (CDSE; Taylor \& Betz, 1983). CDSE consists of five dimensions, namely accurate self-appraisal, gathering occupational information, goal selection, making plans for the future, and problem-solving (Taylor \& Betz, 1983).

In self-concept and vocational identity, Guerra \& Braungart-Rieker (1999) explained that both of these are related to individual difficulties in career decision, caused by psychological difficulties related to family separation, love, and affection issues in the family, and individual's independence. Furthermore, it also impacted the level of self-esteem and individual's anxiety in choosing and career decisions.

In some studies, CDSE can be predicted by social support (Zhong-bao, 2017; Hou, Wu, \& Liu, 2019; Guan, Capezio, Restubog, Read, Lajom, \& Li, 2016; Xing \& Rojewski, 2018; Mahadi, Abdullah, Ph'ng, Hasan, \& Ariffin, 2016; Na \& Moon, 2012). Social support, in this study, refers to Tardy theory (1985) which is a student's perception of teacher, parent, and classmate support behaviors toward students, both in general and specifically (Tardy, 1985). Social support behavior covers five domains, namely: direction (social support which provided and received), disposition (availability and usefulness of social support), description/ evaluation (evaluating and describing social support that has been provided), content (including various types of social support given, namely emotion, instrument, information, and assessment), and networking (related to teacher support in form of resources and social networks needed by students regarding career specifications that need to be decided) (Tardy, 1985; Malecki \& Demaray, 2002).

Individuals with high social support perception have high implications on CDSE. Conversely, individuals with low social 
support perception impacts on how low the CDSE will become. Thus, individuals with low social support perception are vulnerable to having difficulties in career decisions (Wright, Perrone-McGovern, Boo, \& White, 2014). The relationship between social support and CDSE is that the social environment contributes to an individual's self-confidence in career decisions. The social environment contributes to an individual's psychological process, which specifically influences the individual's confidence in his ability to career decision (Jiang, 2017). Furthermore, Brown, Alpert, Lent, Hunt, \& Brady (1988) emphasized the five factors stipulated in social support, namely: acceptance and belonging, appraisal and coping assistance, behavioral and cognitive guidance, tangible assistance and material aid, and modeling.

The first factor related to how individuals are connected to the social environment in where they are, and feeling of worthiness by being loved and valued (Brown et al., 1988). Meanwhile, the second factor is how the social environment provides emotional support which helps individuals to cope with more positive responses (Brown et al., 1988). For the third factor, it is in the form of how the social environment contributes in providing feedback, behavior examples, and thoughts (Brown et al., 1988). Furthermore, the fourth factor is related to material support needed by individuals, especially those that support one individual's confidence in career decisions (Brown et al., 1988). The latter is one example from the social environment, as significant others feel, handle problems, and think (Brown et al., 1988).

Social support not only contributes to increasing CDSE. Social support also has a significant role for earthquake victims and other natural disasters. One of them is a study conducted by Thoresen, Birkeland, Arnberg, Wentzel-Larsen, \& Blix (2019) and Guilaran, Terte, Kaniasty, \& Stephens (2018). Guilaran et al. (2018) found that social support can increase positive outcomes, so psychosocial interventions are highly recommended to improve the positive psychology side. In line with Guilaran et al. (2018), Thoresen et al. (2019) reported that social support was able to reduce anxiety, depression, and trauma.

After the earthquake that occurred in Sigi, high school students must continue their learning activities, even though they are still with anxiety and fear of the earthquake that has occurred and the earthquake that may occur at any time. High school students, they are confronted in terms of career decision (Super, Starishevsky, Matlin, \& Jordan, 1963). On the other hand, high school students cannot be separated from the social environment where they stay. The social environment influences their psychological processes.

Thus, this study aimed to determine the impact of social support on CDSE high school students in Sigi. Thus, we formulate several hypotheses in this study as follows: CDSE is influenced by parents' social support $\left(\mathrm{H}_{1}\right), \mathrm{CDSE}$ is influenced by teachers' social support $\left(\mathrm{H}_{2}\right)$, and CDSE is influenced by classmates' social support $\left(\mathrm{H}_{3}\right)$.

\section{METHODS \\ Participants and Procedures}

Participants were asked for their consent to be involved in voluntary research. The data collection method used a convenience sampling approach (Cohen, Swerdlik, \& Phillips, 2009; Creswell \& Clark, 2013; Cozby \& Bates, 2015; Etikan \& Alkassim, 2016), in which participants who filled out research questionnaire represent the criteria of characteristics' participants who were present at the time of data collection.

The use of this sampling is because the situations after the earthquake. The activities in schools are not effective and conducive. Thus, many students do not go to school. Sigi Regency is one of the locations with a large earthquake. Dolo Selatan is one of the Districts in Sigi Regency with a severe earthquake. Meanwhile, the Dolo Barat District also experienced an earthquake with less severity than the one in Dolo Barat District. The non-conducive learning atmosphere at school also occurred because several classrooms and school buildings were destroyed by the earthquake. Apart from that, it was also affected by earthquakes that had occurred several times. That is the main reason why researchers used convenience sampling (i.e., non-probability sampling) rather than probability sampling.

In probability sampling (Gravetter \& Forzano, 2018), there is an equality of individuals in the population. In this study, the amount of data obtained from each school varied 
greatly. There were schools with a large number of students who aware very enthusiastic about taking part in research, but there were schools with a small number of students attending. Of these, there were some who participated in the research, but there were some students who did not voluntarily participate in the research.

The researchers have permission to report the participant school's name in this paper. Data were collected three times. First, the data collection was carried out at SMKN 5 Sigi and SMAN 10 Sigi. Second, the data collection was carried out in conjunction with the distribution of invitations for the Edu-Fair event organized by the University of Indonesia Alumni Association (ILUNI UI) and a briefing on university entry process (especially University of Indonesia admission) by the research team. Third, the data collection took place just before the closing of the Edu-Fair event.

Specific criteria of participants are high school students in Sigi located in the Districts of Dolo Selatan and Dolo Barat, with adolescence age group ranging from 15 to 19 years old $(M=$ 16.60; $S D=1.699)$. Also, participants recruited were from both girls and boys $(M=1.49 ; S D=$ $.502)$.

\section{Measures}

Before the research measurement tools were distributed to the participants, the measurement tools were adapted by translating them to Indonesian and back-translation (Cruz, Padilla, \& Agustin, 2000). CDSE was measured using Career Decision-Making Self-Efficacy Short-Form Scales (CDMSES-SF; 25-items; Taylor \& Betz, 1983) and social support was measured using Adolescent Social Support Scale (ASSS; 10-items; Malecki \& Demaray, 2002).

For the validity test, researchers used discriminant validity (i.e., factor analysis; Cohen, Swerdlik, \& Sturman, 2013; Kaplan \& Saccuzzo, 2018) by the Lavaan R package. This CDMSES-SF was previously used in Darmayanti \& Salim's research (2020). Similar to Darmayanti \& Salim's (2020) research, this study also used 24-items to measure CDSE; by eliminating one item. This is because there is an item that has $\left(r_{\text {crit }}<.30\right.$; Anastasi \& Urbina, 2016; Kaplan \& Saccuzzo, 2018) and factor loading $(\lambda)<.32$ (Tabachnick \& Fidell, 2007). 25-items in CDMSES-SF have $\mathrm{p}\left(\chi^{2}\right)=.01$; RMSEA $=$
$.080(90 \% \mathrm{CI}=.007-.092) ; \mathrm{CFI}=.781 ; \mathrm{SRMR}$ $=.081$.

Career Decision Self-Efficacy. By using the Career Decision-Making Self-Efficacy Short-Form Scale (CDMSES-SF; Taylor \& Betz, 1983), researcher measured CDSE with 25 items after the reliability have been tested. The reliability of internal consistency coefficient score is $(\alpha=.899)$. CDMSES-SF contains six points Likert-Scale with $1=$ very unsure and 6 = very sure. One example of an item that we use to measure CDSE is 'recognize several majors or career alternatives if I cannot reach the first choice'.

Social support. To find out about teacher support for participants, researcher used the Adolescent Social Support Scale tool (ASSS; Malecki \& Demaray, 2002). In the ASSS measurement tool there are three types of social support from significant others, namely: Teachers' social support, parents' social support, and classmates' social support. ASSS is Likertscale with a range of $1=$ not important and 3 $=$ very important. The sample items used to measure social support are as follows, 'my parents gave me a gift'.

The reliability of internal consistency coefficient score of teachers' social support is ( $\alpha$ $=.771)$, parents' social support is $(\alpha=.697)$, and classmates' social support is $(\alpha=.689)$. Each type of ASSS consisted of 10 items. Furthermore, after the item selection process, there are 9-items to measure teachers' social support, 8-items to measure parents' social support, and 10-items to measure classmates' social support. The item analysis process for social supports is different from CDSE. In ASSS, items were eliminated whenever $\left(r_{\text {crit }}<.25 ; r_{\text {crit }}=.20-.30\right.$ is indicated as 'workable'; Falvey, Holbrook, \& David, 1994). This is due to the consideration that the number of items from each of the teachers' social support, parents' social support, and classmates' social support is only 10 items, which is quite a bit when compared to the number of CDMSESSF items which measure the overall CDSE.

To test the validity, researchers used factor analysis. The result of the teachers' social support validity test is $p\left(\chi^{2}\right)=.200$; RMSEA $=$ $.052(90 \% \mathrm{CI}=.000-.092)$; CFI $=.956$; SRMR $=.058$. Meanwhile, the result of the validity test for parents' social support is $p\left(\chi^{2}\right)=.115$; RMSEA $=.125(90 \% \mathrm{CI}=.091-.161) ; \mathrm{CFI}=$ 
$.742 ;$ SRMR $=.097$. Finally, classmates' social support is valid with $\mathrm{p}\left(\chi^{2}\right)=.115$; RMSEA $=$ $.040(90 \% \mathrm{CI}=.000-.080)$; CFI $=.948$; SRMR $=.069$.

\section{Data Analysis}

Data analysis in this study used descriptive analysis and multiple regression analysis, using IBM SPSS software version 23.00. Descriptive analysis is intended to determine the percentage, mean, and standard deviation of each variable and characteristic of research participants. Moreover, in descriptive analysis, it also examined Pearson correlation analysis which is intended to determine the significance of the relationship among variables. For testing research's hypotheses, multiple regression is applied in analyzing the effect of teachers' social support, parents' social support, and classmates' social support on CDSE. The results of the multiregression analysis not only showed the effect of each variable of social support (i.e., teachers' social support, parents' social support, and classmates' social support) on CDSE, but it also showed the effect of the three social supports on CDSE simultaneously.

\section{FINDINGS AND DISCUSSION}

In this section, there are several research findings of the effect of social support on CDSE. In the beginning, there are results concerning the characteristics of participants and correlation among research variables. Then, reporting the results was followed by the result of CDSE description in order to find out the CDSE level of students after earthquake in Sigi. The final part is the result of regression parents' social support-CDSE, teachers' social support-CDSE, and classmates' social support-CDSE.

\section{Findings}

\section{Descriptive Analysis}

The detailed demographic and characteristic of participants can be seen in Table 1 . The research participants $(N=141)$ came from high schools in the Districts of Dolo Selatan and Dolo Barat, Sigi. Participants in the two districts were divided based on characteristics such as school background, class, sex differences, and age.
Table 1. Participant Characteristics

\begin{tabular}{lrr}
\hline & $\boldsymbol{f}$ & $\boldsymbol{\%}$ \\
\hline School Origin & & \\
SMAN 10 Sigi & 29 & 21 \\
SMAN 7 Sigi & 34 & 24 \\
SMKN 5 Sigi & 14 & 10 \\
SMAS Al-Khairat Bulubete & 37 & 26 \\
MAS Al-Khairat Balamoa & 13 & 9 \\
MAS Vumbu Langi & 8 & 6 \\
Unfilled & 6 & 4 \\
Class & & \\
X & 43 & 30 \\
XI & 61 & 43 \\
XII & 36 & 26 \\
Unfilled & 1 & 1 \\
Sex & & \\
Female & 72 & 51.1 \\
Male & 69 & 48.9 \\
Age & & \\
15 & 10 & 7.1 \\
16 & 53 & 37.6 \\
17 & 50 & 35.5 \\
18 & 21 & 14.9 \\
19 & 6 & 4.3 \\
Unfilled & 1 & .7 \\
\hline
\end{tabular}

Note: SMAN $=$ Sekolah Menengah Atas Negeri (public high school); SMKN = Sekolah Menengah Kejuruan Negeri (public vocational school); SMAS = Sekolah Menengah Atas Swasta (private high school); MAS = Madrasah Aliyah Swasta (private Islamic high school).

In the next part of the descriptive analysis, Pearson correlation analysis was used to determine the relationship among variables in this study. For the Pearson correlation analysis result, we summarized it by including mean and standard deviation scores in Table 2. The result of the Pearson correlation analysis shows that there were three significantly positive correlations on teachers' social support and CDSE $(r=.340 ; p$ $<.01)$, parents' social support and CDSE $(r=$ $.247 ; p<.01)$, and classmates' social support and $\operatorname{CDSE}(r=.302 ; p<.01)$.

Meanwhile, Table 3 shows descriptive analysis for career decision self-efficacy with mean and standard deviation scores of each CDSE's dimension (i.e. accurate self-appraisal, gathering occupational information, goal selection, making plans for the future, and problem solving). Descriptive analysis results indicate that each of the CDSE dimensions has a mean score above the average $(M>3)$. 
Table 2. Correlation among Research Variables

\begin{tabular}{|c|c|c|c|c|c|c|c|c|}
\hline & $M$ & $S D$ & 1 & 2 & 3 & 4 & 5 & 6 \\
\hline Sex Differences & 1.490 & .502 & 1 & & & & & \\
\hline Age & 16.600 & 1.699 & .016 & 1 & & & & \\
\hline Parents' social support & 2.039 & .370 & -.055 & -.100 & 1 & & & \\
\hline Teachers' social support & 2.306 & .347 & $-.205^{*}$ & -.012 & $.498^{* *}$ & 1 & & \\
\hline Classmates' social support & 2.275 & .295 & -.057 & .008 & $.292^{* *}$ & $.441^{* *}$ & 1 & \\
\hline CDSE & 4.447 & .682 & $-.243^{* *}$ & -.080 & $.247^{* *}$ & $.340^{* *}$ & $.302^{* *}$ & 1 \\
\hline
\end{tabular}

Note: ${ }^{* *} p<.01 ;{ }^{*} p<.05$; Sex differences: 1 = Girls, 2 = Boys; CDSE = Career Decision Self-Efficacy.

Table 3. Descriptive Analysis of Career Decision Self-Efficacy

\begin{tabular}{lcc}
\hline Dimensions of CDSE & Mean & $\begin{array}{c}\text { Standard } \\
\text { Deviation }\end{array}$ \\
\hline Accurate self-appraisal & 4.562 & .727 \\
Gathering occupational information & 4.536 & .867 \\
Goal selection & 4.436 & .772 \\
Making plans for the future & 4.607 & .774 \\
Problem solving & 4.111 & .813 \\
\hline
\end{tabular}

\section{Multiple Regression Analysis}

The multiple regression analysis detailed result for the impact of teachers' social support, parents' social support, and classmates' social support on CDSE are described in Table 4. In this case, the researchers report the $F$-ratio score, $R^{2}$, $p$-value $(p)$, and unstandardized coefficient $(B)$, as written in Gravetter \& Wallnau (2013). From Table 4, we can conclude that social support explains $15 \%$ variation on CDSE with $F(3,137)$ $=8.040, p=.000$, indicating that teachers' social support, parents' social support, and classmates' social support statistically significantly predicted CDSE. Furthermore, of each three social support variables, positively and significantly CDSE can be increased by the contribution of teachers' social support $(B=.427 ; p=.027)$ with $11.5 \%$ variation defining on CDSE and classmates' social support $(B=.419 ; p=.042)$ with $9.1 \%$ variation elucidating on CDSE. Meanwhile for parents' social support, it was not found to significantly affect CDSE $(B=.170 ; p=.318)$.

Table 4. Multiple Regression Coefficient of Social Supports on Career Decision Self-Efficacy

\begin{tabular}{|c|c|c|c|c|c|c|}
\hline & \multirow{2}{*}{$B$} & \multirow{2}{*}{$S E$} & \multirow{2}{*}{$t$} & \multirow{2}{*}{$p$} & \multicolumn{2}{|c|}{$95 \% \mathrm{CI}$} \\
\hline & & & & & LL & $\mathbf{U L}$ \\
\hline Constant & 2.183 & .475 & 4.600 & .000 & 1.245 & 3.122 \\
\hline Parents' social support & .159 & .168 & .947 & .345 & -.173 & .492 \\
\hline Teachers' social support & .427 & .191 & 2.232 & .027 & .049 & .805 \\
\hline Classmates' social support & .419 & .204 & 2.053 & .042 & .015 & .823 \\
\hline$R$ & .387 & & & & & \\
\hline$R^{2}$ & .15 & & & & & \\
\hline$\Delta R^{2}$ & .131 & & & & & \\
\hline \multicolumn{7}{|c|}{$F(3,137)=8.040 ; p<.001$} \\
\hline
\end{tabular}




\section{Discussion}

In 2018, earthquakes hit the province Central Sulawesi, Indonesia. The earthquake occurred twice. In Central Sulawesi, earthquakes also hit Sigi Regency, as an area that felt the impact of the earthquakes. So that high school students stay focused on their future, they are faced with a defining career period.

The result of this study indicated that only teachers' social support and classmates' social support have significantly affected high school students' CDSE in Sigi Regency. These findings supported the research of Hou et al. (2019), Garcia, Restubog, Bordia, Bordia, \& Roxas (2015), and Zhong-bao (2017), which in the first hypothesis he stated that Social support would positively affect the CDSE significantly. However, social support-CDSE significance criteria was found in teachers' social supportCDSE and classmates' social support-CDSE, while there was no significant result found in the parents' social support-CDSE.

For descriptive analysis, we found a mean CDSE score above the average (4.447 > $3)$. The score indicates that after the earthquake that occurred in Sigi Regency, Central Sulawesi Province, high school students had a CDSE above the average. This finding also shows that strong self-efficacy to decide on a career is accompanied by strong skill on accurate selfappraisal, gathering occupational information, making plans for the future, goal selection, and problem-solving.

Referring to the results of this study, students' confidence in their ability to decide on careers could be increased with the support of their friends and teachers. According to Kulcsar, Dobrean, \& Gati (2019), there are three things that contribute to students when determining their careers in the future, namely: Readiness, orientation, and information. Readiness, orientation, and information on this career can be obtained from the surrounding environment, especially friends and teachers. Post-earthquake, although High school students have the motivation to continue their undergraduate education, they still feel fear and anxiety if at any time an earthquake occurs. This resulted in High school students being less focused on education and careers in the future. On the other hand, Wentzel, Battle, Russell, \& Looney (2010) found that classmates and teachers increased the motivation of high school students towards their current education and future careers. Thus, High school students become more prepared for their careers by indicating their belief in the ability to decide on a career (Kulcsar et al., 2019), focused and career-oriented (Kulcsar et al., 2019), and looking for some information (Kulcsar et al., 2019) related to careers based on the support of their friends and teachers.

The significance of teachers' social support-CDSE and classmates' social support-CDSE indicated that teachers' social support and classmates' social support can predict and improve accurate self-appraisal, gathering occupational information, goal selection, making plans for the future, and problem solving. Tobolowsky, Scannapieco, Aguiniga, \& Madden (2019) also explain relationships with friends and teachers that enhance strategy in gaining academic achievement. Teachers and classmates have a significant role for the students, as in giving motivations to the students, setting goals for the students, giving rewards to students' academic performance, giving instructions, class management, and feedback for students (feedback on students' academic performance, students' learning motivation, attributions, and strategies; Schunk, Pintrich, \& Meece, 2014).

The results of the research that showed the influence of social support from friends and teachers on students' CDSEs represented that the presence of friends and teachers was very important for high school students. From the perspective of Tardy (1985), teachers' social support and classmates' social support showed how teachers provide emotional support, provide information, and provide assessments on the career that needs further decision. In addition, the teacher plays a role in helping the students to provide information related to study programs and career specifications that are of interest for the students, in order to increase students' CDSE. Brown et al. (1988) stated that social support, the teacher, is in the form of a feedback given on students' career choices. Thus, students will become more confident of their ability to decide what careers they are interested in. Moreover, a teacher figure became a role model (Brown et al., 1988) for students regarding thoughts, feelings, strategies in solving encountered problems, especially relating to career decision. Role model in this case can also be a type of 
career that appeals as well by their teacher. In short, students will make the teacher their role model in order to become a teacher and assign themselves for teacher training study program.

Related to the significant effect of classmate social support, high school students will ask for their friends' opinions and approval in deciding their careers and determining the course of study at the university that they want to determine. They, who have a close relationship with their classmates, will be more confident in career decision (Kracke, 2002). This is recognized by the support of classmates who contribute to students' confidence on their ability to determine what careers they want (Kracke, 2002). Schunk et al. (2014) added that classmates act as a role model, increasing confidence, and setting student goals.

This study indicated that the parents' social support-CDSE is not significant. In the aftermath of the earthquake, parents are more focused on the recovery of the family's economic conditions. Furthermore, parents (mothers and fathers) still experience trauma and fear when they hear the word 'disaster'. As revealed by El-Hassan \& Ghalayini (2019), the significance of parental support and students' ability on career decision is facilitated by the availability of economic support, the availability of parents in giving guidance to students (Guan, Wang, Liu, Ji, Jia, Fang, ... \& Li, 2015), and parents' education level (Ulas-Kilic, Peila-Shuster, Demirtas-Zorbaz, \& Kizildag, 2018). Thus, parents who are recovering their household economic conditions are more focused on the family's economic conditions, this makes the role of parents is not too significant in terms of student's career planning.

According to Ayriza's study (2011), school counselors have a significant role for their students after earthquake. To improving students' CDSE, school counselors' skill on counseling concern to teachers' social support and classmates' social support. The results of this study are to be a concern for the government to improve teachers' social support and classmates' social support in order to improve the CDSE of high school students. Also, for education, educational psychologists, and educators need to pay attention to the aspects of their assistance and support on students to improve the CDSE of high school students.
This research was conducted in Sigi, Central Sulawesi Province as the area affected by the earthquake. This research involved high school students in Sigi. On the other hand, the research team conducted a Focus Group Discussion with high school students in their juvenile years and who were studying in a high school in Sigi, their parents, and the head principal of SMAN 10 Sigi. Moreover, this research aimed to examine the impact of social support on high school students' CDSE. Data were tested using multiple regression analysis by describing teachers' social support, parents' social support, and classmates' social support to predict the CDSE of high school students. For future research, this study could involve the influence of gender diversity on teachers' social support-CDSE. In addition to gender diversity, further research could also consider demographic aspects in the form of family's economic background as one factor that will also affect high school students' CDSE.

In addition, this study uses non-probability sampling, which does not involve randomization to determine the sample in the population. For further research, in line with the passing of the earthquake that occurred in Sigi Regency, researchers can use probability sampling in the presence of individual equality in the population.

\section{CONCLUSSION}

About the influence of social supports on CDSE, we conclude that CDSE is not influenced by parents' social support, thus the first hypothesis in this study is not accepted. Meanwhile, this research finds that the influence of teachers' social support on CDSE is positively significant, so that the second hypothesis is accepted (i.e., CDSE is influenced by teachers' social support). In addition, significantly positive classmates' social support influences CDSE. This confirms that the third hypothesis is accepted (i.e., CDSE is influenced by classmates' social support).

The findings of this study have an impact on the provision of intervention programs and career counseling to high school students. School psychologists and teachers need to pay attention to the quality of classmates' and teachers' support to increase students' confidence in their ability to decide on their future careers. 


\section{ACKNOWLEDGMENTS}

This research is authors' funded. When collecting the data, this research was supported by Universitas Indonesia Alumni Association/ Ikatan Alumni Universitas Indonesia (ILUNI UI), Yaku Mosikola foundation, and SMAN 10 Sigi.

\section{REFERENCES}

Anastasi, A., \& Urbina, S. (2016). Psychological testing ( $7^{\text {th }}$ ed) (R. H. S. Imam, Trans.). Jakarta: PT Indeks. (Original work published 1997).

Ayriza, Y. (2011). Peningkatkan keterampilan guru bimbingan konseling dalam pemerolehan kesiapan psikologis siswa menghadapi bencana alam. [Increasing skills counseling teacher in students' acquisition of psychological preparedness for natural disasters]. Cakrawala Pendidikan, 30(2), 230-242. https://doi. org/10.21831/cp.v0i2.4230.

BMKG (Badan Meteorologi, Klimatologi dan Geofisika). (2018, 28 September). Gempabumi tektonik M=7.7 Kabupaten Donggala, Sulawesi Tengah pada hari Jumat, 28 September 2018, berpotensi tsunami. [Tectonic earthquake $\mathrm{M}=7.7$ Donggala Regency, Central Sulawesi on Friday, September 28 2018, potential for a tsunami]. https://www.bmkg.go.id/ press-release/?p=gempabumi-tektonikm7-7-kabupaten-donggala-sulawesitengah-pada-hari-jumat-28-september2018-berpotensi-tsunami\&tag $=$ pressrelease\&lang $=$ ID.

Béjar-Pizarro, M., Álvarez Gómez, J. A., Staller, A., Luna, M. P., Pérez-López, R., Monserrat, O., ... \& Herrera, G. (2018). InSAR-based mapping to support decisionmaking after an earthquake. Remote Sensing, 10(6), 1-24. https://doi. org $/ 10.3390 / \mathrm{rs} 10060899$.

Brown, S., Alpert, D., Lent, R., Hunt, G., \& Brady, T. (1988). Perceived social support among college students: Factor structure of the social support inventory. Journal of Counseling Psychology, 35(4), 472-478. https://doi.org/10.1037/0022-
0167.35.4.472.

Cassarino-Perez, L., Crous, G., Goemans, A., Montserrat, C., \& Sarriera, J. C. (2018). From care to education and employment: A meta-analysis. Children and Youth Services Review, 95, 407-416. https://doi. org/10.1016/j.childyouth.2018.08.025.

Cohen, R. J., Swerdlik, M. E., \& Phillips, S. M. (2009). Psychological testing and assessment: An introduction to tests and measurement $\left(7^{\text {th }}\right.$ ed). New York, NY: McGraw Hill.

Cohen, R. J., Swerdlik, M. E., \& Sturman, E. D. (2013). Psychological testing and assessment: An introduction to tests and measurements $\left(8^{\text {th }}\right.$ ed). New York, NY: McGraw Hill.

Cozby, P. C., \& Bates, S. C. (2015). Methods in behavioral research $\left(12^{\text {th }} \mathrm{ed}\right)$. New York, NY: McGraw-Hill.

Creswell, J. W., \& Clark, V.L.P.(2017).Designing and conducting mixed methods research. Thousand Oaks, CA: Sage publications.

Cretney, R. M. (2016). Local responses to disaster. Disaster Prevention and Management, 25(1), 27-40. https://doi. org/10.1108/DPM-02-2015-0043.

Cruz, F. A. D., Padilla, G. V., \& Agustin, E. O. (2000). Adapting a measure of acculturation for cross-cultural research. Journal of Transcultural Nursing, 11(3), 191-198. https://doi. org/10.1177/104365960001100305.

Darmayanti, K. K. H., \& Salim, R. M. A. (2020). The enhanced career decisionmaking self-efficacy by emotional intelligence depended on proactive personality. Electronic Journal of Research in Education Psychology, 18(50), 121142. $\quad$ https://doi.org/10.25115/ejrep. v18i50.2685.

Dominey-Howes, D. (2015). Seeing 'the dark passenger'-reflections on the emotional trauma of conducting post-disaster research. Emotion, Space and Society, 17, 
55-62. $\quad$ https://doi.org/10.1016/j. emospa.2015.06.008.

El-Hassan, K., \& Ghalayini, N. (2019). Parental attachment bonds, dysfunctional career thoughts and career exploration as predictors of career decision-making self-efficacy of Grade 11 students. British Journal of Guidance \& Counselling, 48(5), 597-610. https://doi.org/10.1080/0 $\underline{3069885.2019 .1645296 .}$.

Etikan, I., Musa, S. A., \& Alkassim, R. S. (2016). Comparison of convenience sampling and purposive sampling. American Journal of Theoretical and Applied Statistics, 5(1), 1-4. $\quad$ https://doi.org/10.11648/j. ajtas.20160501.11.

Falvey, P., Holbrook J., \& David C. (1994). Assessing students. Hong Kong, China: Longman.

Garcia, P. R. J. M., Restubog, S. L. D., Bordia, P., Bordia, S., \& Roxas, R. E. O. (2015). Career optimism: The roles of contextual support and career decision-making self-efficacy. Journal of Vocational Behavior, 88, 10-18. https://doi. org/10.1016/j.jvb.2015.02.004.

Gravetter, F. J., \& Wallnau, L. B. (2013). Statistics for the behavioral sciences $\left(9^{\text {th }}\right.$ ed). Belmont, CA: Cengange Learning.

Gravetter, F. J., \& Forzano, L.-A. B., (2018). Research method for the behavioral sciences. Boston, MA: Cengage.

Guan, P., Capezio, A., Restubog, S. L. D., Read, S., Lajom, J. A. L., \& Li, M. (2016). The role of traditionality in the relationships among parental support, career decision-making self-efficacy and career adaptability. Journal of Vocational Behavior, 94, 114-123. https://doi. org/10.1016/j.jvb.2016.02.018.

Guan, Y., Wang, F., Liu, H., Ji, Y., Jia, X., Fang, Z., ... \& Li, C. (2015). Career-specific parental behaviors, career exploration and career adaptability: A three-wave investigation among Chinese undergraduates. Journal of Vocational Behavior, 86, 95-103. https://doi.org/10.1016/j.jvb.2014.10.007.

Guerra, A. L., \& Braungart-Rieker, J. M. (1999). Predicting career indecision in college students: The roles of identity formation and parental relationship factors. The Career Development Quarterly, 47(3), 255-266. https://doi. org/10.1002/j.2161-0045.1999.tb00735.x.

Guilaran, J., de Terte, I., Kaniasty, K., \& Stephens, C. (2018). Psychological outcomes in disaster responders: A systematic review and meta-analysis on the effect of social support. International Journal of Disaster Risk Science, 9(3), 344-358. https://doi. org/10.1007/s13753-018-0184-7.

Ho, R., Fan, F., Lai, A., Lo, P., Potash, J., Kalmanowitz, D., Nan, J., ... \& Chan, C. (2012). An expressive arts-based and strength-focused experiential training program for enhancing the efficacy of teachers affected by earthquake in China. Creative Education, 3(1), 67-74. https://doi.org/10.4236/ce.2012.31011.

Hou, C., Wu, Y., \& Liu, Z. (2019). Career decision-making self-efficacy mediates the effect of social support on career adaptability: A longitudinal study. Social Behavior and Personality: An international journal, 47(5), 1-13. https:// doi.org/10.2224/sbp.8157.

Hou, F. S., Li, T., Li, J., Hu, X. Q., Liu, Z. Y., \& Yuan, P. (2011). The effects of demographic features on differences in sensitivity between PCL-C and SCL-90 scores in a follow-up study in high school students in the Wenchuan earthquake region. Biomedical and Environmental Sciences, 24(6), 642-648. https://doi. org/10.3967/0895-3988.2011.06.008.

Jiang, Z. (2017). Social support and career psychological states: An integrative model of person-environment fit. Journal of CareerAssessment, 25(2),219-237.https:// doi.org/10.1177/1069072715621019.

Jurnaliston, R. (2018, 29 September). Gempa bumi berkekuatan 5,5 magnitudo guncang Sigi, Sulawesi Tengah. [An 
earthquake measuring 5.5 magnitude shakes Sigi, Central Sulawesi]. Kompas. com. https://regional.kompas.com/ $\mathrm{read} / 2018 / 09 / 29 / 12333221 /$ gempa-bumiberkekuatan-55-magnitudo-guncang-sigisulawesi-tengah.

Kaplan, R. M., \& Saccuzzo, D. P. (2018). Psychological testing: Principles, applications, and issues $\left(9^{\text {th }} \mathrm{ed}\right)$. Boston, MA: Cengange Learning.

Kracke, B. (2002). The role of personality, parents and peers in adolescent's career exploration. Journal of Adolescence, 25(1), 19-30. https://doi.org/10.1006/ jado.2001.0446.

Kulcsar, V., Dobrean, A., \& Gati, I. (2019). Challenges and difficulties in career decision making: Their causes, and their effects on the process and the decision. Journal of Vocational Behavior, 116 (Part A), $103346 . \quad \underline{\text { https://doi. }}$ org/10.1016/j.jvb.2019.103346.

Mahadi, H., Abdullah, N., Ph'ng, L. M., Hasan, H., \& Arifin, H. (2016). Self-esteem, social support and career decisionmaking among technical engineering students. The Social Sciences, 11(12), 2971-2976. https://medwelljournals.com/ abstract/?doi=sscience. 2016.2971.2976.

Malecki, C. K., \& Demaray, M. K. (2002). Measuring perceived social support: Development of the child and adolescent social support scale (CASSS). Psychology in the Schools, 39(1), 1-18. https://doi. org/10.1002/pits.10004.

Mesidor, J. K., \& Sly, K. F. (2019). Religious coping, general coping strategies, perceived social support, PTSD symptoms, resilience, and posttraumatic growth among survivors of the 2010 earthquake in Haiti. Mental Health, Religion \& Culture, 22(2), 130-143. https://doi.org/1 $\underline{0.1080 / 13674676.2019 .1580254}$.

Mooney, M., Tarrant, R., Paton, D., Johal, S., \& Johnston, D. M. (2017). Getting through: Children's effective coping and adaptation in the context of the Canterbury,
New Zealand, earth quakes of 20102012. Australasian Journal of Disaster and Trauma Studies, 21(1), 19-30. https:// mro.massey.ac.nz/handle/10179/11348.

Na, T.-K., \& Moon, S.-W. (2012). The mediating effect of career decision-making selfefficacy on the relationship between social support of professors and career preparation behavior of foodservice and culinary art Majors-Focus on the university in Chungcheong province. Culinary science and hospitality research, 18(2), 106-117. http://www.koreascience.or.kr/ article/JAKO201218553923363.page.

Newnham, E. A., Balsari, S., Lam, R. P. K., Kashyap, S., Pham, P., Chan, E. Y., ... \& Leaning, J. (2017). Self-efficacy and barriers to disaster evacuation in Hong Kong. International Journal of Public Health, 62(9), 1051-1058. https://doi. org/10.1007/s00038-017-1036-8.

O'Toole, V. M., \& Friesen, M. D. (2016). Teachers as first responders in tragedy: The role of emotion in teacher adjustment eighteen months post-earthquake. Teaching and Teacher Education, 59, 57-67. https://doi. org/10.1016/j.tate.2016.05.012.

Pan, X., Liu, W., Deng, G., Liu, T., Yan, J., Tang, Y., ... \& Xu, M. (2015). Symptoms of posttraumatic stress disorder, depression, and anxiety among junior high school students in worst-hit areas 3 years after the Wenchuan earthquake in China. Asia Pacific Journal of Public Health, 27(2), NP1985-NP1994. https:// doi.org/10.1177/1010539513488625.

Platt, S., \& Drinkwater, B. D. (2016). Postearthquake decision making in Turkey: Studies of Van and Izmir. International Journal of Disaster Risk Reduction, 17, 220-237. https://doi.org/10.1016/j. ijdrr.2016.03.010.

Schunk, D., H., Pintrich, P., R., \& Meece, J. L. (2014). Motivation in education: Theory, research and application $\left(4^{\text {th }} \mathrm{ed}\right)$. Upper Saddle River, NJ: Pearson New International Edition. 
Super, D. E., Starishevsky, R., Matlin, N., \& Jordaan, J. P. (1963). Career development: Self-concept theory (CEEB Research Monograph No. 4). New York, NY: College Entrance Examination Board.

Tabachnick, B. G., \& Fidell, L. S. (2007). Using multivariate statistics. New York, NY: Allyn \& Bacon/Pearson Education.

Tardy, C. H. (1985). Social support measurement. American Journal of Community Psychology, 13(2), 187-202. https://doi.org/10.1007/BF00905728.

Taylor, K., M., \& Betz, N. E. (1983). Applications of self-efficacy theory to the understanding and treatment of career indecision. Journal of Vocational Behavior, 22(1), 63-81. https://doi.org/10.1016/00018791(83)90006-4.

Thoresen, S., Birkeland, M. S., Arnberg, F. K., Wentzel-Larsen, T., \& Blix, I. (2019). Long-term mental health and social support in victims of disaster: comparison with a general population sample. BJPsych open, 5(1), 1-6. https://doi.org/10.1192/ bjo.2018.74

Tobolowsky, B. F., Scannapieco, M., Aguiniga, D. M., \& Madden, E. E. (2019). Former foster youth experiences with higher education: Opportunities and challenges. Children and Youth Services Review, 104, 1-11. https://doi. org/10.1016/j.childyouth.2019.05.039.

Ulas-Kilic, O., Peila-Shuster, J. J., DemirtasZorbaz, S., \& Kizildag, S. (2018). Career decision-making self-efficacy of young adolescent students in Turkey. International Journal of School \& Educational Psychology, 8(Sup 1), 3848. https://doi.org/10.1080/21683603.201 $\underline{8.1552220 .}$.

UNICEF. (2016, 25 July). Braving danger to take an exam in Syria. https://www.youtube. com/watch? $\mathrm{v}=\mathrm{U} 3 \mathrm{BsPo} \mathrm{NFqE}$.

UNICEF. (2017, 28 April). Emergency lessons: In crisis, education is vital. https://www. youtube.com/watch?v=ZtkqM3tNqZY.

Wang, W., Fu, W., Wu, J., Ma, X. C., Sun, X. L., Huang, Y., ... \& Gao, C. G. (2012). Prevalence of PTSD and depression among junior middle school students in a rural town far from the epicenter of the Wenchuan earthquake in China._PLoS One,_7(7), 1-10. https://doi.org/10.1371/ journal.pone.0041665.

Wentzel, K. R., Battle, A., Russell, S. L., \& Looney, L. B. (2010). Social supports from teachers and peers as predictors of academic and social motivation. Contemporary Educational Psychology, 35(3), 193-202. https://doi. org/10.1016/j.cedpsych.2010.03.002.

Wright, S. L., Perrone-McGovern, K. M., Boo, J. N., \& White, A. V. (2014). Influential factors in academic and career selfefficacy: Attachment, supports, and career barriers. Journal of Counseling \& Development, 92(1), 36-46. https://doi. org/10.1002/j.1556-6676.2014.00128.x.

Xing, X., \& Rojewski, J. W. (2018). Family influences on career decision-making self-efficacy of chinese high vocational students. New Waves-Educational Research and Development Journal, 21(1), 48-67. https://www.viethconsulting.com/ members/publication/new waves article. php?aid=34912219.

Zhong-bao, C. A. O. (2017). The relationship between social support and career decision-making self-efficacy of senior students in vocational colleges. Journal of Hubei Normal University (Philosophy and Social Science), 3, 24. http:// en.cnki.com.cn/Article_en/CJFDTotalHBSX201703024.htm. 